\title{
O RURAL-URBANO E A ESCOLA BRASILEIRA
}

\section{(ensaio de interpretação sociológica)}

\section{Dulce Consuelo Andreatta Whitaker*}

\section{I - INTRODUÇÃO}

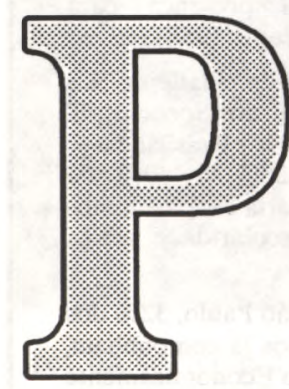

ara compreender como vejo a questão da educação rural (e urbana) na sociedade brasileira hoje, é preciso, logo no início deste artigo, superar a razão dualista que costuma dicotomizar os fenômenos humanos, contrapondo-os em pares antagô-

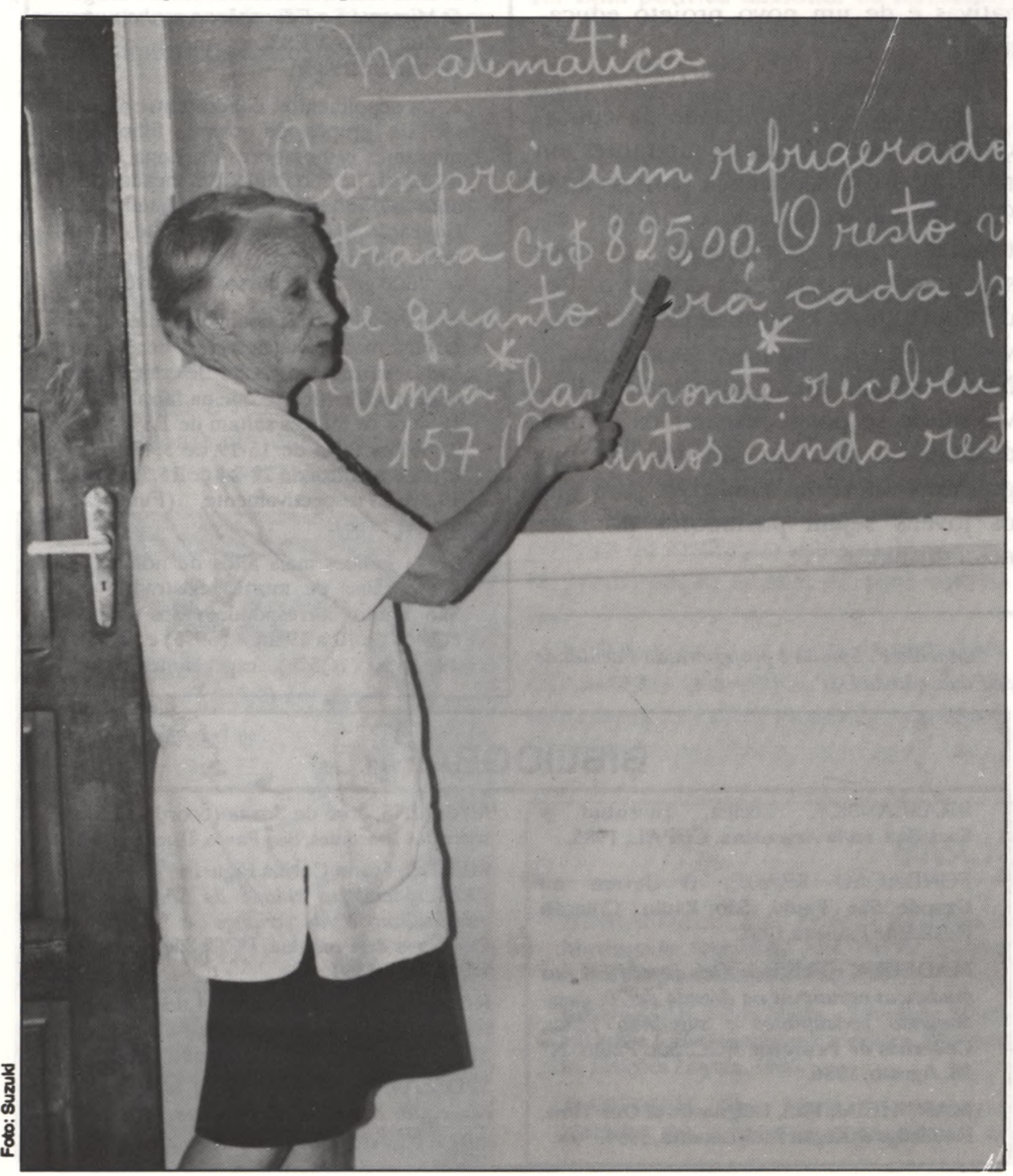

nicos: cultura $x$ natureza, rural $x$ urbano, países desenvolvidos $x$ países subdesenvolvidos, etc. Tal maneira conceitual de organizar o raciocínio pode ajudar a compreender os fenômenos a partir da ciência positivística, mas é obscurecedora do real em sua complexidade (totalidade) ${ }^{1}$.

Somente o raciocínio dialético pisrmite observar como os objetos reais se interpenetram de forma ora articulada ora integrada, mas sempre compondo com a totalidade. Superar a razão dualista é, portanto, o primeiro passo para compreender como se articulam o rural e o urbano no Brasil hoje.

A questão que se apresenta é pois como superar a visão dualista na investigação de um rural e um urbano que aparecem ao senso comum tão diferenciados?

Em primeiro lugar devemos fazer a crítica de um certo senso comum que afeta muitas vezes até o pensamento acadêmico e diz: "O Brasil foi até os anos 30/40 um país agrário. Hoje é um país moderno (urbanizado, industrializado etc). Sua taxa de urbanização é de tal ordem que no ano 2.000 o Estado de São Paulo, por exemplo, terá somente $4 \%$ da população no campo. Conclusão: o rural vai desaparecer".

Tal forma de raciocínio, útil para entender aparências, pode levar a conclusões perigosas. A experiência da Inglaterra, país pioneiro da Revolução Industrial, mostra que o rural não desaparece (1989). É importante então que pensemos a educação rural (e urbana) no contexto de um rural-urbano unificados, tal como apontado por Martins nos anos 70 (Martins 1979). Embora a crítica à razão dualista se faça desde os anos 60 , na Sociologia, conforme mostra o mesmo Martins, quer me parecer que a visão dualista do rural-urbano é mais forte do que a crítica, uma vez que ela permanece até nos departamentos univerŝitários, que muitas vezes separam sociólogos em rurais e urbanos. $\mathrm{E}$ no entanto, todos sabem dos riscos epistemológicos que envolvem o pesquisador, quando trata separadamente o rural e o urbano na sociedade brasileira - unificados que estão hoje pelo capital, através principalmente do avanço do complexo agro-industrial.

Vejamos concretamente como se apresenta essa unificação. Para tanto basta observar a região agrícola mais próspera do país (o Nordeste do Estado de São Paulo com os ricos municípios de Araraquara e Ribeirão Preto, por exemplo). Ali não é preciso muita 
sociologia para perceber tal unificação. É suficiente caminhar um pouco pelos extensos canaviais que dominam o espaço geográfico para constatar a existência de ruas e placas com números para identificação. Nesses espaços desaparece a antiga fazenda de cafe, que correspondia ao modelo "hacienda", com sua diversificação de produção animal e vegetal (gado. porcos, perus, horta, pomar, etc). No seu lugar apareceu a "plantation" de cana-de-açúcar, comandada pelas usinas, configurandose nelas tudo aquilo que a razão dualista pensava como urbano: a fabricação de açúcar e álcool com toda maquinaria, toda subsunção real do trabalho ao capital, toda administração "racional", todo aparato tecnológico e mais a contabilidade de custos que caracteriza a moderna empresa. Elementos pensados pelo senso comum como urbanos e que lá estão, no meio do canavial.

Em contrapartida, se se pergunta a um cortador de cana (trabalhador rural) onde fica sua residência, é muito provável que ele diga que mora na cidade (enquanto alguns operários da usina moram no campo).

Evidentemente, nada disso significa que o rural está desaparecendo. Muito pelo contrário, fazendo pesquisa nesta região agrícola, que é a mais rica do país, encontrei pequenos sítios tradicionais no meio dos canaviais, fenômenos de resistência que têm merecido estudos recentes (Whitaker 1984: Coelho 1990: Alvarenga Reis 1991).

Mas o mais interessante é que aquele rural bucólico, cheio de passarinhos, hortas e pomares, que o senso comum imagina estar desaparecendo, pode ser encontrado nas pequenas cidades (asfaltadas) em quase todos os quintais e principalmente nos daquelas pessoas que se mudaram recentemente do campo. Uma esposa de um cortador de cana que morava em terras da usina (campo), quando entrevistada afirmou ter mudadó para a cidade para poder plantar horta e frutas, etc. (Whitaker, 1984).

Um outro aspecto da questão - do qual a Sociologia nem sempre se dá conta - e este vai ser o mais importante para se discutir a educação rural (e ur- bana) é o fato de que, ao avançar pelo campo, através do complexo agro-industrial, o capitalismo não só não urbaniza o campo como desurbaniza as pequenas cidades da região, que se transformam em cidades-dormitório de trabalhadores volantes. É um processo, portanto, de desruralização e de desurbanização ${ }^{2}$. São dois processos claros na região dos canaviais à volta de Araraquara e principalmente no eixo Araraquara-Ribeirão, com inúmeras cidadezinhas transformadas em cidadesdormitório de cortadores de cana - encravadas todas elas numa paisagem que vai se homogeneizando. Paralelamente, essa homogeneização, eliminando a diversidade, vai criando a desintegração ambiental pela destruição do ecossistema.

Esta leitura do espaço que se pode fazer observando a paisagem, ou lendo as estatísticas de produção de cana do Estado de São Paulo é, no entanto, apenas o plano mais geral das tendên- cias da agricultura na região. Escondidos pela grandiosidade dos canaviais e das usinas, no entanto, seres humanos resistem.

Resistem em pequenos sítios, resistem em bairros rurais (Coelho 1990: Alvarenga Reis 1991) e resistem em Assentamentos de Trabalhadores $\mathrm{Ru}$ rais. Tal como ocorre no Brasil todo, a luta pela terra é também nessa região um traço de resistência. Mesmo entre cortadores de cana, trabalhadores volantes em geral, não há homogeneidade, conforme demonstra a literatura sociológica. Há categorias diferenciadas que vão desde os trabalhadores fixados pelas usinas através da moradia até migrantes de outros Estados, que passam parte do ano no Estado de São Paulo. Essa extrema diversidade, dentro de uma região aparentemente homogeneizada pelo complexo agro-industrial, pode dar uma pequena idéia da heterogeneidade que caracteriza o Brasil (rural e urbano).

\section{II - A QUESTÃO DA EDUCAÇÃO}

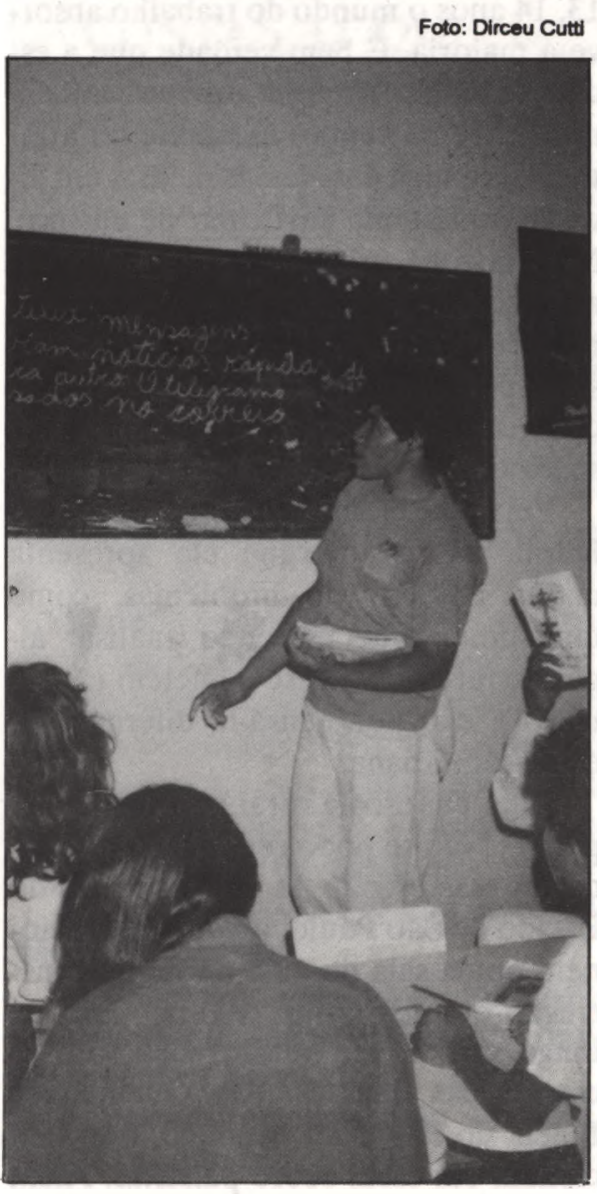
dentro dessa visão - rural-urbano integrados num país de extrema heterogeneidade econômica e cultural - que vou discutir o problema da Educação.

Num país de tal complexidade cultural, como se apresenta a escola pública? Rural ou urbana, ela tem três características fundamentais, a saber:

a) é urbanocêntrica, isto é, voltada para conteúdos que informam e são informados no processo de urbanização;

b) é sociocêntrica, isto é, voltada para interesses de certas classes sociais;

c) é etnocêntrica, isto é, privilegia a cultura relativa ao mundo ocidental - a chamada racionalidade do capitalismo, fortemente atrelada ao avanço científico tecnológico.

O que tem isso de errado? Em princípio, nada. A escola tem mesmo que ensinar as bases matemáticas da ciência ocidental, a norma culta da linguagem e a História Oficial, porque é desses conteúdos que as pessoas necessitam para conquistar a cidadania numa sociedade que se diz moderna. $\mathrm{O}$ proble- 
ma está em que a escola brasileira não estabeleceu condições para fazer a conexão entre esses conteúdos culturais e aqueles que parecem "menores", mas existem em maijor quantidade na sociedade nacional. Que conteúdos são esses? Tais conteúdos são as práticas culturais - também diversificadas pelo país heterogêneo - e que caracterizavam uma população que foi rural até poucas décadas. A escola brasileira não apresenta metodologias apropriadas para estabelecer essa ponte necessária entre os diferentes tipos de cultura - que estão baseados em códigos diferentes, esse é um dado fundamental.

O homem brasileiro, mesmo quando urbano, tem um substrato rural porque seus pais, ou no mínimo seus avós, nasceram e viveram na zona rural. Em todos os estratos sociais no Brasil encontramos pessoas com dificuldades para viver a vida urbana, lidar com os equipamentos urbanos. Ao mesmo tempo, não sabem mais lidar com a natureza porque desprezam o rural. Desenraizados do rural, vivemos num mundo urbano em desintegração. O capitalismo unificou economicamente o rural e o urbano e os homens transitam (vivem e trabalham) igualmente nesses espaços integrados. Por não compreendermos isso, vivemos hoje um processo de barbárie, no qual se destroem ao mesmo tempo a natureza e os equipamentos urbanos.

Enquanto isso o que faz a escola rural ou urbana - desligada totalmente de tais complexas realidades?

Continua urbanocêntrica, sociocêntrica e etnocêntrica. Digo etnocêntrica para não dizer racista, já que continua voltada aos interesses de uma elite branca que até hoje não conseguiu resolver nem os problemas do analfabetismo no país. Diga-se de passagem, a escola não tem culpa como escola. Ela é assim porque as classes dominantes (das quais saem os técnicos do MEC) são assim. Minhas pesquisas mostram que os professores, na ambigüidade do seu papel, fazem às vezes esforços sinceros para mudar, mas nem sempre o conseguem, porque permanecem presos às malhas burocráticas da administração centralizada da educação no Brasil.

Foto: Arquivo Cem

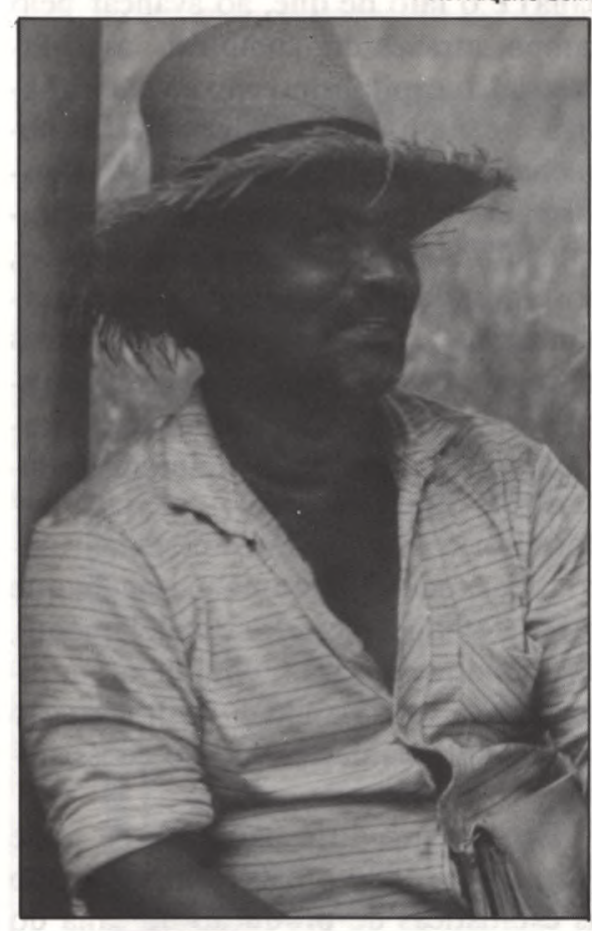

Tal escola, quando instalada na zona rural, simplesmente não funciona. Multisseriada, unidocente, com terminalidade precoce, atende a uma pequena quantidade de crianças, já que aos 12 , 13,14 anos o mundo do trabalho absorve a maioria. É bem verdade que a escola instalada na zona urbana também não funciona bem (o que pode ser atestado pela fuga das classes médias em direção ao sistema particular de ensino). Mas na zona urbana muitas crianças e adolescentes conseguem permanecer na escola até a $8^{a}$ série, o que embora seja apenas o cumprimento de um preceito constitucional, neste país já é um sucesso.

Vejamos, então, o caso da Educação Rural, 'não só porque ela apresenta maior número de problemas, como também porque pretendo analisar alguns equívocos que se cometem em relação a ela, por pensá-la diferente da educação urbana.

Falar em escola rural no Brasil é um perigo. Não se pode generalizar ao descrever essa escola. As escolas rurais do Estado de São Paulo, ainda que funcionem numa sala de aula ou numa construção que não atinja $100 \mathrm{~m}^{2}$, nem de longe podem ser comparadas com as escolas das ilhas do Rio Guamá, em Belêm do Pará, por exemplo, que funcionam em casas sobre palafitas. Além disso, as escolas rurais do Estado de São Paulo estão em processo de agrupamento e evidentemente uma Escola Agrupada, com certo grau de administração burocrática, nada tem a ver com escolas rurais do Piauí que funcionam na casa da professora - alguém que chegou à $3^{\text {a }}$ série da escola fundamental e hoje luta bravamente para alfabetizar crianças. No Estado de São Paulo as professoras são formadas em $100 \%$ dos casos. No Estado do Rio de Janeiro há um município que, segundo reportagem da Revista Nova Escola ( $n^{\circ} 41$ agosto de 1990) oferece infra-estrutura perfeita às 25 escolas rurais espalhadas pelo seu interior. É o município de Resende, cuja riqueza agropecuária, segundo a mesma reportagem, permite oferecer aos 900 alunos dessas escolas o mesmo conforto dos prédios escolares urbanos e chega até ao fornecimento gratuito dos uniformes escolares para todos que não tenham condições de comprar. No entanto, apesar dessas condições invejáveis, os pais estavam aproveitando o transporte escolar gratuito para enviar as crianças à cidade para cursar da $1^{\text {a a }} 4^{\mathrm{a}}$ série, o que resultava em vagas ociosas nas escolas rurais e deficit de vagas nas urbanas. A reportagem trata então dos inventivos recursos pedagógicos que estão sendo utilizados por aquela Secretaria Municipal de Cultura para segurar as crianças menores nas escolas rurais.

O exemplo sugere aquilo que já sabemos. A escola não é responsável pelo desenraizamento do homem do campo. Ele é expulso pelo avanço econômico. Mas ele sugere também algo que nem todos sabem. Os pais pressentem que seus filhos, estudando na cidade, terão acesso mais imediato àqueles conteúdos que são necessários a uma melhor integração ao mundo moderno (urbanocêntricos, portanto). Apoiadas ou não por melhores recursos das prefeituras, as escolas rurais estarão sempre semivazias; ou porque as crianças foram absorvidas pelo mundo do trabalho ou porque preferem estudar na cidade. $\mathrm{O}$ problema, portanto, não está na escola como estrutura material ou instituição. O problema é sistêmico e parte dele pode ser localizado na política educacional que assola o país. 


\section{III - A POLÍTICA EDUCACIONAL PARA EDUCAÇÃO RURAL}

D reocupados com a população desenraizada que se encaminha dos campos para as cidades, engrossando nelas circuitos de miséria e sofrimento, os técnicos encarregados da política educacional perdem de vista a totalidade. Enquanto os artífices da política agrícola em Brasília criam uma Lei Agrícola que privilegia os grandes proprietários, propõem modernidade, competitividade, produtividade e declaram que os incompetentes (leia-se "pequenos") devem sair do mercado (palavra mágica no mundo atual), deixando o espaço para aqueles que sejam capazes de verticalizar ${ }^{3}$, a política educacional se comporta de forma esquizofrênica em relação ao contexto, mantendo as diferenciações na educação rural.

No Estado de São Paulo, por exemplo, está ocorrendo, desde o governo passado, um aparentemente louvável processo de agrupamento, em substituição à ineficiente escola isolada. No seu lugar surgem as Escolas Agrupadas, em geral nos Distritos, pequenas Vilas próximas às escolas transferidas. Realizando pesquisa sobre escolaridade nos Assentamentos do Horto Silvânia na região de Araraquara, visitei as escolas agrupadas freqüentadas pelos filhos dos assentados nos Distritos de Silvânia e Bueno de Andrade. Entrevistando professoras que lá trabalham, minhas pesquisadoras encontraram um certo entusiasmo pelo agrupamento das escolas (natural dentro das condições do isolamento anterior) mas que se baseava muito no fato de que novas medidas relativas ao enriquecimento curricular iriam permitir a fixação do homem ao campo(!?).

Mal refeita do susto (afinal,no Estado mais urbanizado do país ressurge das cinzas o ruralismo pedagógico) tratei de investigar a legislação das Escolas Agrupadas. Achei bonito: transporte para todas as crianças e estrutura administrativa, aliviando o trabalho dos professores. Chamou-me atenção, no entanto, que nessa proposta vem um enriquecimento curricular, cuja base principal é o ensinar as crianças a fazer

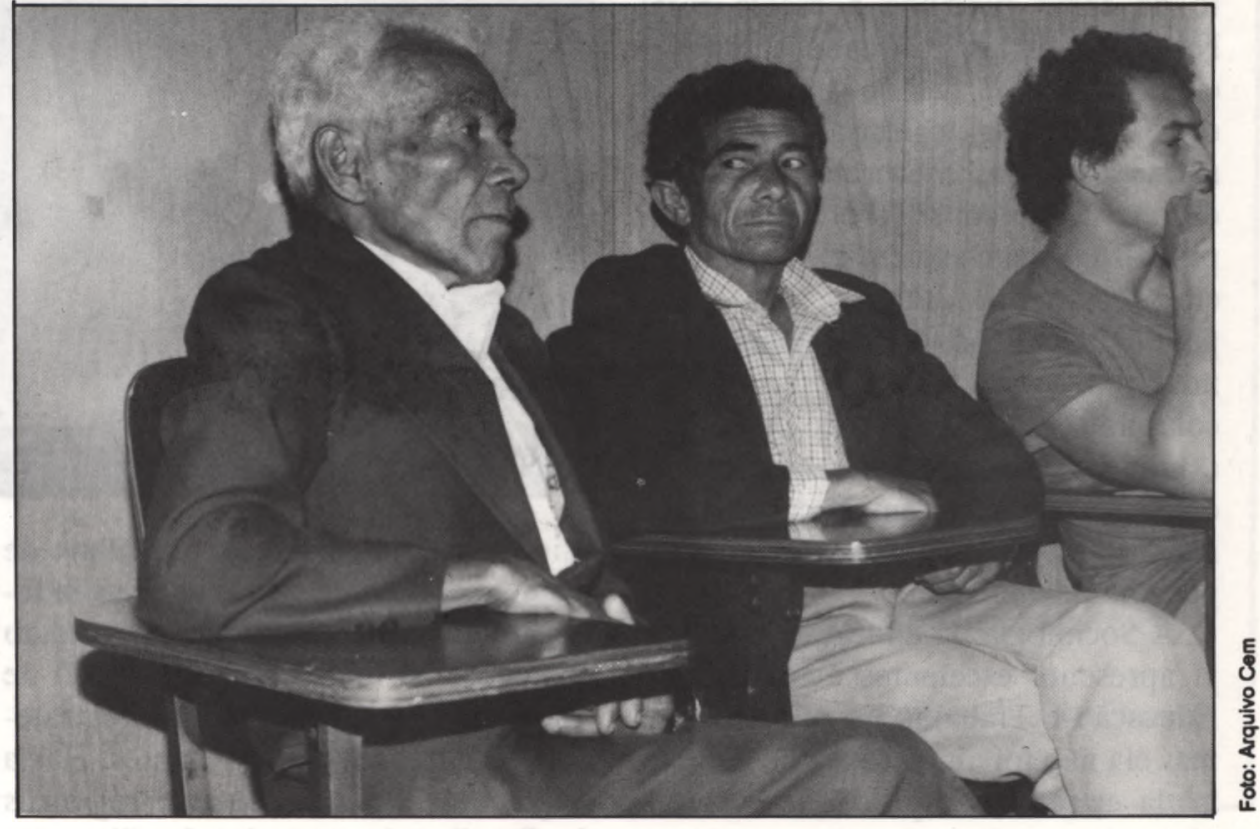

horta. O documento que consultei fala também em economia doméstica (!) e corte e costura, mas o "quente" da proposta, pelo menos no discurso das professoras entrevistadas, é a confecção da horta. Já havia, inclusive, nas escolas visitadas, hortas bem cuidadas. No futuro serão criadas granjas, e assim "além de ajudar a fixá-los no campo, estaremos ensinando às crianças coisas que são da realidade delas" 4 . Segundo as professoras, as crianças adoram trabalhar na horta e a partir daí desenvolve-se um discurso otimista com relação ao futuro da Educação Rural.

Ora, se retomarmos agora o eixo central desta discussão - aquela idéia de que o Capitalismo e o Industrialismo unificaram o rural e o urbano, nada disso tem sentido. Tem sentido fazer horta, mas não com esse objetivo. Tem sentido fazer horta em qualquer escola, até numa escola no Morumbi ou na Consolação, se houver espaço e a poluição permitir. As professoras não percebem que as crianças gostam de trabalhar na horta porque crianças gostam de atividade. A horta é uma atividade educativa que aproxima as crianças da natureza e crianças urbanas inclusive podem usufruir tais resultados. Não tem o menor sentido, porém, ensinar a fazer horta como forma de segu- rar as pessoas no campo. Em primeiro lugar não vai segurá-las; conforme já vimos, outros são os fatores de expulsão.

Outro equívoco - mais grave - dessa proposta é que ela, no fundo, pretende preparar dois tipos de cidadania (se é que se pode falar em cidadania neste país): uma, para viver as delícias da vida urbana (abstraindo-se é claro a poluição, as neuroses do trânsito, dos assaltos, etc,etc,etc) e outra para permanecer num bucólico mundo das hortas e pomares que o complexo agro-industrial pretende suprimir.Para os primeiros, capricha-se no conteúdo relativo à vida urbana, enquanto aos restantes ensina-se a fazer hortas e granjas. Conforme palavras de uma mãe muito crítica, moradora de um dos Assentamentos pesquisados "não preciso que meu filho aprenda a fazer na escola aquilo que já sabe".

A frase acima desvela os vários equívocos da política educacional, que por não atuar sobre uma realidade integrada, pensa o mundo ainda de forma dualista. A proposta pretende "ensinar às crianças que o rural e o urbano se complementam", o que envolve raciocínio dualista - coisas que se complementam é porque são diferentes ou estão separadas. 
Os equívocos da política educacional em relação à educação rural são resultados, a meu ver, do desconhecimento de como funciona a escola rural. Não só a escola é urbanocêntrica. A ciência também. Estuda-se muito a escola através da legislação, exaustivamente criticada, interpretada, observada, etc. Estudam-se problemas de aprendizagem em escolas de periferia ou em áreas metropolitanas. Não é fácil para os Sociólogos e Pedagogos (urbanos) irem à zona rural e observar as escolas no seu funcionamento cotidiano o universo concreto das relações entre escola e o espaço em que se situam mais, os grupos humanos que dela dependem/independem.

A Sociologia da educação no Brasil já apresenta excelentes estudos sobre Educação e Trabalho no mundo rural, mas ela não foi ainda capaz de dar conta da extrema complexidade das relações entre cultura escolar e culturas tradicionais, nas condições do país hoje, em graus diferenciados de avanço da agroindústria sobre realidades heterogêneas.

E bota heterogeneidade nisso. Quando realizei minha pesquisa para doutorado, no início dos anos 80 , preocupava-me o processo ideológico de controle do trabalho nos canaviais da região. Apliquei então um experimento, para captar relações entre escola e trabalho numa situação muito específica. Colhi redações, com um tema que era muito próximo às crianças numa situação de controle. Os pequenos redatores eram crianças de $2^{\mathrm{a}}$ a $8^{\mathrm{a}}$ série com moradias em três diferentes tipos de espaço: o primeiro espaço era tido como rural (escolas isoladas nas fazendas à volta da cidadezinha da Santa Lúcia); o segundo era tido como urbano (a escola de Santa Lúcia, município distante 18 $\mathrm{km}$ de Araraquara em processo de desurbanização); o terceiro eram os pequenos sítios que sobrevivem em meio à "plantation", que abrigavam também uma escola isolada próxima e inclusive com crianças já estudando em Santa Lúcia.

O interessante foi que, ao buscar o específico, encontrei uma heterogeneidade muito grande: filhos de cortadores de cana, capatazes e funcionários da

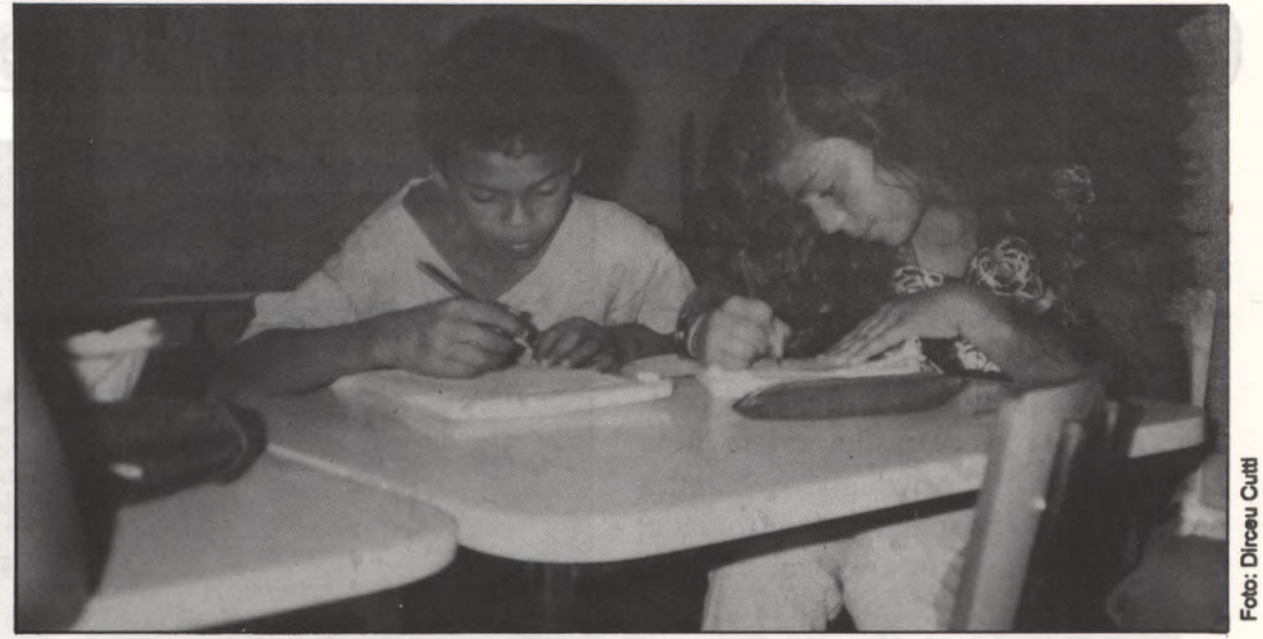

usina estudando ao lado de filhos de pequenos sitiantes e da classe média local. Filhos de famílias cujos avós estão na região há muito tempo ao lado de filhos de migrantes de diferentes categorias de trabalhadores volantes. Havia fragmentos de sub-culturas regionais do Brasil todo naquelas famílias tentando reconstruir suas vidas...

O tema da redação era "Descreva sua casa e um dia na sua família" e através dele pude descobrir fatos surpreendentes. Entre eles, o fato de que crianças de $2^{\mathrm{a}}, 3^{\mathrm{a}}$ série, filhos de pais analfabetos ou semi-analfabetos, contrariamente ao que se propala por aí, têm competência lingüística. Foram elas que me forneceram a chave para compreender muito o processo de controle ideológico que se desenrola em relação ao trabalho da cana. E pude descobrir também, através dessas redações, que os filhos dos pequenos sitiantes que resistem ao avanço dos canaviais escrevem com mais criatividade, com mais liberdade de expressão, com mais fluidez. E são eles que têm maior compreensão do mundo do trabalho e da natureza, que se concretizam até à volta da casa onde moram. Enquanto isso, os filhos dos cortadores de cana, que moram em casas cedidas pela usina, num espaço que imita o espaço urbano de forma caricatural, talvez pelo confinamento em que vivem, apresentam menor criatividade e maior pobreza vocabular. Quanto às crianças que moram no espaço em desurbanização de Santa Lúcia, também refletiram esse desequilíbrio em suas redações.

Minha intenção não era pedagógica ou lingüística quando realizei essa investigação. Eu estava interessada num processo ideológico. Mas do ponto de vista pedagógico, o que mostra essa parte do meu trabalho? Mostra que é uma falácia da política educacional pensar a educação rural separada da urbana. O universo dessas crianças é a totalidade rural-urbano e quando elas vão à escola é porque seus pais anseiam que adquiram conteúdos que lhes permitam decifrar os códigos da sociedade industrial.

Permanece, no entanto, o problema de como ensinar-lhes esses códigos. Entre pedagogos e professores há uma rica polêmica a esse respeito, que conforme pretendo demonstrar está também informada pela razão dualista. São duas as grandes correntes, no que se refere à escolarização, não só de crianças da zona rural como de todos os filhos das camadas exploradas da sociedade nacional. A primeira delas, que eu chamaria de pedagogia romântica, engloba as várias tendências culturalistas e afirma que os conteúdos escolares devem enfocar o cotidiano da criança informando-se e formando-se a partir do meio cultural em que a criança vive. Inspiradas (mal inspiradas, talvez) nas teorizações de Paulo Freire, as práticas pedagogicas dessa corrente correm o risco de não passar desse primeiro nível, que é importante, sem dúvida, mas não é o suficiente para a socialização que se pretende nesse mundo industrializado. Para muitos defensores dessa pedagogia romântica, não importa que o professor tenha apenas a $3^{\mathrm{a}}$ série do $1^{\circ}$ grau. O professor é um líder da co- 
munidade e como tal deve ser capaz de dar afeto às crianças, auxiliar poderoso no processo de socialização. Tudo que os seguidores dessa corrente afirmam é verdadeiro. O drama é que todas as afirmativas da corrente oposta também o são. Quais são essas afirmativas? A principal delas é a de que a obrigação da escola é preparar para a plena cidadania e para tal há conteúdos fundamentais - realizar bem as quatro operações e cálculos de porcentagem, conhecer regras de bem falar, dominar enfim os conteúdos básicos do núcleo comum de disciplinas do currículo escolar, por mais abstratos que possam ser. Quem em sã consciência poderia negar que isto é verdadeiro? O drama está em que as crianças dessas camadas exploradas nem sempre aprendem esses conteúdos, já que são estranhos à sua cultura. Para esta corrente, que eu chamo de Pedagogia Modernizadora, o fracasso escolar resulta da falta de competência técnica. Mas basta conhecer um pouco das teorias de Piaget para saber que não só as crianças, como qualquer ser humano, aprendem apenas conteúdos para os quais tenham esquemas de assimilação. Assim, enquanto a Pedagogia Romântica peca pelo risco de empobrecimento do currículo, esta Pedagogia da Competência peca pelos perigos da não-aprendizagem.

Se a criança não tem esquemas para assimilar conteúdos da cultura urbana das classes privilegiadas e etnocêntricas é preciso um programa para superar essa dicotomia. Essas duas correntes se digladiam porque não superaram a lógica dualista, que separa rural e urbano, popular e erudito, cultura intelectual e cultura de massa, como se existissem sempre em compartimentos estanques. Ao perder de vista a dialética do processo humano, a Pedagogia sempre faz propostas impossíveis de realizar. Não estou afirmando que a Pedagogia tem qualquer culpa pelo fracasso da escolarização, cujas causas são bem conhecidas no Brasil.

Mas se é verdade que existe um curso de Pedagogia que prepara profissionais para desenvolver metodologias adequadas à aprendizagem, deveria ser também verdade que a escola no Brasil tivesse certo sucesso.
Pretendo ter demonstrado que do ponto de vista educacional, num país como o Brasil, generalizações são perigosas (e não só do ponto de vista educacional). A tentativa de homogeneização também é perigosa, porque tentar eliminar diversidades culturais é tão perigoso quanto eliminar a diversidade da natureza. A centralização da administração escolar, quer em nível da União, quer das capitais dos Estados, constrói camisas-de-força que impedem a criatividade dos professores. Para superar a razão dualista que estabelece a separação entre a educação rural e a urbana, o melhor caminho é estabelecer uma larguíssima autonomia nas escolas, através da qual diretores e professores possam buscar os melhores conteúdos a serem trabalhados em cada caso sem nunca perder de vista a ponte que deve ser estabelecida entre a cultura da criança e a cultura da escola. A autonomia de cada escola (e não municipalização porque municipalizar é empobrecer) é a única maneira de garantir que ela faça sobre os conteúdos, o enfoque rural-urbano no grau mais adequado.

O Brasil não é mais um país rural, mas também não é um país moderno comó querem os economistas que transitam (de avião) no eixo Rio-São Paulo-Brasília-Nova York e nunca viram um igarapé ou uma escola rural do Mato Grosso a $300 \mathrm{~km}$ da Delegacia de Ensino mais próxima.

Conforme assinalou Luiz Felipe de Alencastro, em brilhante artigo publicado pela Folha de S. Paulo, nem os cientistas sociais conhecem bem este país com sua imensa e variada diversidade, aguardando levantamento antropológico adequado (Alencastro 1990). É muita pretensão portanto do MEC ou das Secretarias Estaduais estabelecerem regras gerais para todas as escolas. No dia em que os necessărios recursos forem colocados para resolver nossa crise educacional, ainda será preciso muita vontade política para superar os obstáculos. E vontade política so se produz a partir da autonomia. Com esta condição talvez seja possível superar o dualismo que ainda forma sociólogos que se dividem entre rurais e urbanos.

*Dulce C.A.Whitaker é professoralpesquisadora do programa de Pós-graduação em Sociologia Rural e Urbana da UNESP Araraquara.

\section{NOTAS}

1. Capra mostra, até para a Fisica, como a Ciência Moderna conceitua o Cosmo como um Universo de partículas em movimento perpétuo - o homem participando desse movimento - e não mais um mero observador que analisa "pedaços" recortados pela Ciência Positivística (Capra 1983).

2. O avanço da "plantation", segundo Morse, provoca hiper metropolização, porém esvazia as "aldeias". (Veja-se por exemplo Morse 1975 ou Whitaker 1984).

3. Resultados dessa política podem ser avaliados pela Edição de 31-08-1991 do jornal Folha de S.Paulo.

4. Extraído do depoimento de uma professora.

\section{BIBLIOGRAFIA}

1- ALENCASTRO, L.F. - Compreensão da realidade nacional é um desafio para cientistas sociais. in: Caderno Letras. Folha de S. Paulo, 22 de setembro de 1990.

2- ALVARENGA REIS, S. - O Engenho Velho e os Batistas de Carvalho. Dissertaçăo de Mestrado apresentada ao programa de Sociologia Rural e Urbana da Unesp em Araraquara (mimeo), 1991.

3- CAPRA, E. - 0 Tao da Física. Cultrix, São Paulo, 1983.

4- COELHO, M. - Bairro dos Machados: entre o sonho e a realidade. Dissertação de Mestrado apresentada ao programa de So- ciologia Rural e Urbana da UNESP em Araraquara, 1990.

5- MARTINS, J.S: - Sobre o modo capitalista de pensar. Hucitec, São Paulo, 1978.

6- MORSE, P. - Evolução das Cidades Latino-Americanas. Cadernos CEBRAP, $\mathrm{n}^{\circ} 22$, 1975.

7- WHITAKER - Ideologia e Práticas Culturais: o controle ideológico do trabalhador da cana. Tese de Doutorado, USP, São Paulo, (mimeo), 1974.

8- WILliANS, R. - O Campo e a Cidade, Cia. das Letras. São Paulo, 1989. 